\title{
STANISŁAW GRODŹ \\ Chrześcijańska posługa uzdrawiania w Afryce w perspektywie teologicznej koncepcji Chrystusa-uzdrowiciela
}

\begin{abstract}
Afrykańską teologię chrześcijańską zaczęto uprawiać na plaszczyźnie akademickiej dopiero pod koniec lat pięćdziesiątych XX w. Jednak pierwsze, poważne próby opracowania kluczowych zagadnień chrystologii z perspektywy afrykańskiej podejmowane przez afrykańskich teologów ${ }^{1}$ pochodza $z$ przełomu lat siedemdziesiatych i osiemdziesiatych XX w. Zaczęto wtedy badać czy przy użyciu takich rodzimych, afrykańskich kategorii jak przodek, uzdrowiciel, władca, mistrz inicjacji czy najstarszy brat można wyrazić kim jest i czego dokonal Jezus Chrystus. Cele tych działań były przynajmniej dwojakie. Z jednej strony chciano w ten sposób pomóc Afrykanom w zrozumieniu zbawczej roli Jezusa Chrystusa, która wcześniej wyrażana byla w kategoriach uksztaltowanych w środowisku semickim i indoeuropejskim. Z drugiej strony chodziło o swoista rehabilitację afrykańskich pojęć, które zostały uznane za niegodne zastosowania w wyrażaniu chrześcijańskich prawd wiary przez europejskich duchownych w końcu XIX i w pierwszej połowie XX w.

Inkulturacja chrześcijaństwa w Afryce nie jest zjawiskiem nowym i dokonywała się nie tylko na płaszczyźnie liturgii, ale również na płaszczyźnie doktrynalnej na długo przed oficjalnym uznaniem jej konieczności przez Kościoły misyjne $^{2} . \mathrm{Z}$ wielu powodów tym ostatnim trudno przychodzi uznanie osiagnięć

\footnotetext{
${ }^{1}$ Chodzi tu o teologów pochodzących z Afryki oraz o tych, którzy są silnie związani z afrykańskim kontekstem.

${ }^{2}$ Tą niezbyt szczesśliwą nazwą określa się te kościoły chrześcijańskie w Afryce, które zostały założone przez przybyłych spoza Afryki misjonarzy i nadal utrzymują silne więzi z kościołami założycielskimi. Natomiast przez „afrykańskie kościoły rodzime/niezależne” rozumie się te wspól
} 
dokonanych przez afrykańskie Kościoly rodzime. Część z tych dokonań miało i ma niewątpliwie charakter synkretyczny i wymaga, jeśli nie odrzucenia, to przynajmniej znacznego oczyszczenia. Jednak wiele $z$ nich zasługuje nie tylko na uwagę, ale i na uznanie, gdyż można w nich dojrzeć działanie Bożego Ducha, który tchnie kędy chce (por. J 3, 8).

Zajmując się zagadnieniami inkulturacji chrześcijaństwa w Afryce na płaszczyźnie doktrynalnej, pisałem już o próbach przedstawiania Jezusa jako afrykańskiego przodka i uzdrowiciela ${ }^{3}$. Pomimo opracowywania tych zagadnień na plaszczyźnie akademickiej i niejako „wciaggania” ich w sferę życia chrześsijan z Kościołów misyjnych należy pamiętać, ze afrykańska teologia jest nadal w znacznej mierze - jak to określił Ghańczyk Kofi Appiah-Kubi - teologia „ustna”" afrykańskich Kościołów niezależnych ${ }^{4}$. Wierni gromadzący się w tych kościolach jako pierwsi wśród afrykańskich chrześcijan zaczęli zwracać większą uwagę na fakt, że Jezus jest wielkim lekarzem, uzdrowicielem, zwycięzcą ziemskich mocy par excellence i że przez Niego Bóg zlewa na ludzi swój dar całkowitego uzdrowienia. Realne doświadczenia uzdrowień, doznawane przez wielu Afrykanów w ramach posługi sprawowanej w kościołach niezależnych stają się dowodem wypełniania Jezusowego nakazu uzdrawiania chorych, wskrzeszania umarlych i wypędzania zlych duchów (Mt 10, 8) ${ }^{5}$.

W niniejszym artykule chcę zwrócić uwagę na niezmiernie istotną dla Afrykanów rolę posługi uzdrawiania. Można odnieść wrażenie, że w afrykańskim

noty, które zostały założone przez Afrykanów i zasadniczo utrzymują dystans do wyżej wspomnianych wspólnot.

${ }^{3}$ Por. S. G r o dź: Ancestralna chrystologia Ch. Nyamitiego. „Nurt SVD”. R. 34: $2000 \mathrm{nr}$ 3(90) s. 81-97; T e n ż e. »Wielkim uzdrowicielem jest ten Jezus, dziecko Boga«. Afrykańskie poszukiwania chrystologiczne. „Nurt SVD”. R. 37: 2003 nr 4 s. 103-125. Zob. także - T e n ż e: Chrystus-Król czy Chrystus-Przodek? Chrystologiczne poszukiwania afrykańskich chrześcijan. „Znak". R. 50: 1998 nr 521 s. 103-112.

${ }^{4}$ Podsumowujac, ich ustna teologia w przeciwieństwie do zachodniej, liberalnej teologii jest »nie definicja, ale opisem; nie stwierdzeniem, ale opowiadaniem; nie doktryna, ale świadectwem; nie ksiażkq, ale ludźmi; nie summq teologiczna, lecz pieśnia!« (wszystkie thumaczenia cytatów z pozycji francusko- i angielskojęzycznych pochodza od autora). K. A p p i a h - K u b i: Christology. W: A Reader in African Christian Theology. Red. J. P a r r a t t. London 1997 s. 74 . M. K i r we n (The Missionary and the Diviner. Contending Theologies of Chrisitan and African Religions. Maryknoll 1985 s. 91-92, 97) zwrócił uwagę na fakt istnienia starej, chrześcijańskiej pieśni, w której Jezus jest nazywany wróżbita.

Rodzime afrykańskie Kościoly chrześcijańskie odpowiadaja: w imie Jezusa wielkiego uzdrowiciela, nasze kościoły nie sa jedynie kościolami, ale także szpitalami. Zatem przynieście wszystkie wasze zmartwienia zwiqzane $z$ bezrobociem, bieda, problemami zwiqzanymi z czarownictwem, pechem, wrogami, niepłodnościa, smutkiem, ślepota, itp. Jezus jest gotów zbawić wszystkich, którzy przychodza do Niego z wiarq. My leczymy, a Bóg lub Jezus uzdrawia (K. A p p i a h $\mathrm{K}$ u b i, dz. cyt., s. 73). 
kontekście jej nieobecność, czyli brak powiązania plaszczyzny wiary z realiami codziennego życia, oznaczałaby podważenie sensowności i konieczności istnienia religii. Postrzeganie Jezusa jako uzdrowiciela (także w afrykańskim znaczeniu tego pojęcia) stwarza chrześcijanom w Afryce możliwości poszukiwania chrześcijańskich sposobów realizacji tej posługi.

\section{Zbawienie a zdrowie}

W pojęciu wielu Afrykanów zbawienie nie odnosi się jedynie do przyszłego życia, ale jest konkretnie związane $\mathrm{z}$ codziennością, zatem w bezpośredni sposób dotyczy kwestii zdrowia. Skoro Pismo święte stwierdza, że Jezus przyszedł na świat po to, by ludzie mieli życie w obfitości (J 10, 10), to ogrom ludzkich cierpień wymaga wyjaśnienia tego, co dzieje się z Bożym darem życia i na ile poważnie Kościól traktuje Jezusowe polecenie pełnienia posługi uzdrawiania ${ }^{6}$. Postrzeganie Jezusa jako uzdrowiciela w perspektywie afrykańskiej nie jest jedynie teoretyczną konstrukcją teologiczna, ale ważnym elementem chrześcijańskiej codzienności z wyraźniejszym praktycznym odniesieniem, niż pojmowanie Go jako przodka.

Rozpatrując uzdrowicielska posługę Chrystusa jako wyzwanie dla Kościoła w Afryce, protestancki teolog nigeryjski Emele M. Uka zauważa rozdźwięk, jaki dokonał się między działalnością Jezusa a praktyką głównych Kościołów chrześcijańskich, które oddzieliły uzdrowienie duchowe od fizycznego ${ }^{7}$. Appiah-Kubi twierdzi, że promując europejską medycynę, Kościół zsekularyzował posługę uzdrawiania. Stawianie troski o zdrowie ciała na pierwszym miejscu sztucznie oddziela ją od troski o zdrowie człowieka jako psychofizycznej osoby funkcjonującej w społeczności. Natomiast Gwinejczyk Cécé Kolié mówi o dążeniu do zawłaszczenia sfery zdrowia Afrykanina i próbie uzależnienia afrykańskich

${ }^{6}$ K. A p p i a h- Ku bi: The Church's Healing Ministry in Africa. „Ecumenical Review”. R. 27: 1975 s. $230-231$.

${ }^{7}$ E. M. U k a odwołuje się do M. Kesley'a (Healing and Christianity. London 1973): w efek cie załamania się zachodniej cywilizacji w VI i VII w. po Chrystusie ludzie niepewni ziemskiego jutra zaczęli wyglądać lepszego życia po śmierci. Zdrowie duszy stało się ważniejsze niż zdrowie ciała. Dlatego np. sakrament namaszczenia chorych stał się „ostatnim namaszczeniem”. Wyraźniej złączono grzech i chorobę, chociaż Jezus wykazał, że obie sprawy nie muszą być ze sobą ściśle związane. Rozwój myśli teologicznej zmierzał ku przekonaniu chrześcijan, że Bóg udzielał daru uzdrawiania jedynie dawniej. Jednocześnie uznano, że do świata widzialnego trzeba podchodzić racjonalnie, na jego własnych, materialnych zasadach. Chorobę potraktowano jako element materialnego świata i jako dopuszczoną przez Boga karę dla utrzymania czlowieka w posłuszeństwie (E. M. U k a: Christ's Healing Ministry. W: The Church and Healing. Red. E. L a r t e y i inni. Frankfurt 1994 s. $147-148)$. 
chrześcijan od zachodniej medycyny przez odrzucenie wszystkich afrykańskich rytuałów i terapii ${ }^{8}$.

Narzucanie Afrykanom przez Kościoły misyjne własnego pojęcia zdrowia doprowadziło do paradoksalnej sytuacji. W pojęciu Afrykanów Pan życia (Bóg) dba o zdrowie czlowieka, czyli o utrzymywanie promującej życie harmonii w samym czlowieku, w jego relacjach $z$ innymi ludźmi i w jego odniesieniu do świata niewidzialnego. Ta harmonia jest zachwiana szczególnie w czasie rytów przejścia (narodzinach, inicjacji w dorosłe życie, śmierci), w tak szczególnych sytuacjach jak np. ciąża oraz w dotykających człowieka chorobach i nieszczęściach. Jednak sposób, w jaki Kościoły misyjne przedstawiaja Jezusa nie jest czytelny dla Afrykanów i nie pozwala im dostrzec tego, jak jest On obecny w tych sytuacjach i jak przywraca utraconą harmonię ${ }^{9}$.

Kościoły misyjne ostro potępiały specyficzne dla rodzimego kontekstu kulturowego Afryki tzw. wspólnoty strapienia, niosące pomoc w odzyskaniu utraconej harmonii. Opisując jedną ze takich wspólnot z Tanzanii, Aylward Shorter, antropolog i kapłan ze Zgromadzenia Misjonarzy Afryki, ukazał niemal klasyczną sytuację, w ktorrej duchowni z Kościołów misyjnych potępili tę wspólnotę jako „kult diabła”, nie zadając sobie trudu zbadania przesłanek jej istnienia i wypełnianej przez nią roli. Duchowny, który podzielał ten pogląd, ale wprowadził religijny rytuał egzorcyzmujący duchy, został za to skrytykowany przez swoich kolegów-duchownych. Jednak wprowadzony przez niego rytuał zyskał popularność wśród chrześcijan, którzy dotąd we wspólnocie strapienia znajdowali rozwiązanie trapiących ich problemów, a przez uznanie jej za kult diabła zaczęli doznawać duchowej rozterki ${ }^{10}$.

\footnotetext{
${ }^{8}$ Stwierdzenia te nie negują zasług i wysiłków misjonarzy w dziedzinie ochrony zdrowia w Afryce (K. A p p i a h-K u b i: The Church's Healing Ministry, dz. cyt., s. 230-231; C. K o li é: Jésus guérisseur? W: Chemins de la christologie africaine. Red. F. K a b a s élé, J. D o r é, R. L u n e a u. Paris 1986 s. 190-191). C. Kolié (s. 184-185) dostrzega, że zetknięcie medycyny zachodniej $\mathrm{z}$ afrykańską dokonało się $\mathrm{w}$ kontekście kolonialnej dominacji, a misyjne dzieło medyczne wykorzystywano czasem jako element potwierdzający doskonałość nowej religii.

${ }^{9}$ K. A p p i a h-Ku bi: The Church's Healing Ministry, dz. cyt., s. 230-231; C. Ko 1 i é: Jésus guérisseur?, dz. cyt., s. 190-191.

${ }^{10}$ Podejście S h o r t e r a do zagadnienia ukazuje jednak jego europejski punkt widzenia. Akcentuje on, że według wyników jego badań ceremonie sprawowane we wspólnocie nie miały charakteru religijnego i były otwarte dla wyznawców różnych religii. To samo miał wcześniej twierdzić medium - przywódca wspólnoty (A. S h o r t e r: Mediumship, Exorcism and Christian Healing. „African Ecclesiastical Review”. R. 22: 1980 nr 1 s. 29).
} 


\section{Synteza elementów afrykańskich i chrześcijańskich}

Od dziesiątków lat Afrykanie sami dokonywali syntezy chrześcijańskiej posługi uzdrawiania z elementami rodzimej kultury w ramach afrykańskich Kościołów niezależnych. Działalność ta rozwinęła się w wyniku odrzucenia przez Kościoły misyjne afrykańskiego pojęcia uzdrawiania oraz usilnego dyskredytowania rodzimych uzdrowicieli, a także jako reakcja na problemy społecznoekonomiczne $^{11}$. Członkowie Kościołów niezależnych wierzą, że całościowe uzdrowienie czlowieka jest darem Boga udzielonym wspólnocie wierzących. W zgodzie z afrykańskim pojmowaniem rzeczywistości wierzą też, że choroba ma swoje naturalne, nadnaturalne i nadprzyrodzone przyczyny. Kościoły niezależne poważnie traktują istnienie mocy szkodzących ludziom, zwykle określanych mianem czarownictwa i uznaja je za wysłanników diabła. Jednocześnie wyraźnie ukazuja, że Bóg pokonuje zło i jest źródłem sily, z którego ludzie mogą czerpać w każdej chwili swego życia. Appiah-Kubi podkreśla, że Kościoły te uznaja afrykański sposób pojmowania religii i medycyny jako wywodzących się z tego samego źródła. Medyczna opieka jest ważna i potrzebna, ale nie jest w stanie poradzić sobie ze wszystkimi sytuacjami. Akcent położony na wiarę staje się wyraźnym wskazaniem, że to Bóg dokonuje ostatecznego uzdrowienia ${ }^{12}$.

Wiele Kościołów niezależnych stara się dystansować od rytuałów wywodzących się z kontekstu religii afrykańskich. Do istotnych różnic między rytualnymi praktykami proroków uzdrawiających z Kościołów niezależnych i rodzimych uzdrowicieli amerykański antropolog Wyatt MacGaffey zaliczył używanie przez pierwszych rytualnego białego stroju, czystej wody zamiast leczniczych mikstur i rezygnacji z używania wszelkich amuletów. MacGaffey zinterpretowal to jako podejmowana przez proroków próbę zdystansowania się od aury wieloznaczności, otaczającej rodzimego uzdrowiciela ${ }^{13}$. W religiach afrykańskich

${ }^{11}$ R. Gr a y: Black Christians and White Missionaries. New Haven 1990 s. 103.

${ }^{12}$ Kościoły niezależne dokonują pionierskiej pracy, łącząc uzdrawianie, duszpasterstwo i przesłanie o zbawieniu (K. A p p i a h - K u b i: The Church's Healing Ministry, dz. cyt., s. 235236; T e n ż e: Man Cures, God Heals: Religion and Medical Practice among the Akans of Ghana. New York 1981 s. 81-124). Według M. L. D a n e e la (Towards a Theologia Africana? The Contribution of Independent Churches to African Theology. „Missionalia”. R. 12: 1984 nr 2 s. 84) Kościoły niezależne najwyraźniej ze wszystkich sięgaja po wzór Chrystusa - rodzimego uzdrowiciela.

${ }^{13}$ W. M a c Gaff e y: Modern Kongo Prophets. Religion in a Plural Society. Bloomington 1983 s. 167 . G. K a c z y ń s k i (Bunt i religia w Afryce czarnej. $Z$ badań nad ruchami religijnymi w Zairze. Wrocław 1979 s. 116) pisze: Charakterystyczna cechq metody Kimbangu bylo leczenie wiara i niestosowanie praktyk magicznych. Oczyszczenia z grzechów oraz wiara w Jezusa była wylacznym warunkiem odzyskania zdrowia przez chorego. Wzorem do naśladowania byla dla Kimbangu postać Jezusa, a rytual wielu obrzedów uzdrawiania stosowany przez niego par excellence przypomina sceny ewangeliczne. Zob. rôwnież - M. S c h o f f e l e e r s: Folk Christology in 
rodzimy uzdrowiciel spełnia często wiele funkcji - od leczenia ludzi, przez troskę o przywracanie i utrzymywanie harmonii we wspólnocie, po podejmowanie mistycznych ataków na tych, którzy tej harmonii na plaszczyźnie indywidualnej i spolecznej zagrażają ${ }^{14}$.

Uka podkreśla, że posługa uzdrawiania jest częścią składową misji Chrystusa, którą Kościół ma realizować. Apostołowie wyraźnie podjęli sakramentalne podejście Jezusa do uzdrawiania, w którym gesty i elementy materialne były znakami działającej mocy Boga, a uzdrawiający musiał trwać w łączności z Duchem Świętym, aby sprawowane przez niego czynności przyniosly autentyczne uzdrowienie. Chrześcijanie muszą pamiętać, że Jezus jest wzorem duszpasterza i że u podstaw wszystkich posług wypełnianych przez Kościół stoi Duch Święty, Pocieszyciel i Uzdrowiciel, który napełnia wiernych i kieruje nimi także w kontynuowaniu uzdrowicielskiej misji Jezusa. Pominięcie uzdrawiania w działalności pastoralnej i liturgii sprawia, że Kościoły nie są w stanie zaspokoić najgłębszych pragnień wiernych i tracą społeczne znaczenie ${ }^{15}$.

Zdaniem Koliégo Afrykanie wyraźnie dostrzegą, że Jezus niesie im pomoc w chwili zmagania się z siłami zła dopiero wtedy, gdy chorzy znajdą swoje miejsce w liturgicznej celebracji, a Kościół autentycznie zaangażuje się w walkę o sprawiedliwość. Dopiero wtedy ewangeliczne przepowiadanie będzie wiarygodne w Afryce. Kościół musi wziąć pod uwage afrykańskie rozumienie zdrowia i choroby, aby Jezusowe przesłanie o zbawieniu naprawdę dotarło do Afrykanów, dodaje Appiah-Kubi. Kolié sugeruje zatem konieczność wnikliwszego rozpatrzenia, dzięki darom Ducha Świętego, zdolności uzdrawiania posiadanej przez przodków ${ }^{16}$. Akańskie przysłowie: Ludzie leczq, Bóg uzdrawia z tytułu książki

Africa. The Dialectics of the Nganga Paradigm. "Journal of Religion in Africa”. R. 19: $1989 \mathrm{nr} 2$ s. 167; R. Gr a y: Black Christians, dz. cyt., s. 106; M. L. D a n e e l: Towards a Theologia Africana?, dz. cyt., s. 84.

${ }^{14}$ Aura wieloznaczności, która otacza rodzimego uzdrowiciela jest często wytwarzana przez samych pacjentów-klientów, którzy oczekuja niekiedy od niego przeprowadzenia mistycznego ataku na wrogów. Efektem tego jest rodzący się w ludziach lęk - skoro uzdrowiciel może zaatakować innych, może też i zaatakować mnie, gdy ktoś inny z takim żądaniem do niego się zwróci. Zob. krótki tekst w języku polskim na ten temat, zawierający odniesienia do obszernej nowej literatury w języku angielskim i francuskim (S. G r o dź: Uzdrowiciele, wróżbici, czarownicy - problem adekwatnego opisu kontaktów Afrykanów ze światem nadnaturalnym. „Przegląd Religioznawczy”. R. $2003 \mathrm{nr} 4$ s. 210).

${ }^{15}$ E. U k a: Christ's Healing Ministry, dz. cyt., s. 146-147, 150-151.

${ }^{16}$ C. K o 1 i é: Jésus guérisseur?, dz. cyt., s. 192. Głównym zadaniem chrześcijaństwa w Afryce jest bardziej demistyfikacja i zegzorcyzmowanie choroby, niż jej wyleczenie (tamże, s. 197; K. A p p i a h - K u b i: The Church's Healing Ministry, dz. cyt., s. 230-231). 
Appiah-Kubiego wyraźnie ukazuje rolę rodzimego uzdrowiciela w tym proce$\operatorname{sie}^{17}$.

Nigeryjski teolog Ukachukwu Manus przypomina, że żaden medyczny system nie rozwiązuje wszystkich problemów związanych ze zdrowiem i że duchowe uzdrowienie jest tak samo ważne jak uzdrowienie cielesne. Aby jednak działalność na płaszczyźnie duchowej nie stawała się farsą, uzdrowiciel musi być czlowiekiem modlitwy, który dąży do realizacji ideału świętości w życiu ${ }^{18}$.

Szeroko podzielane w Afryce przekonanie o wpływie duchów na ludzkie życie sprawia, że pacjenci szukający uleczenia często opisują swoją chorobę w kategoriach owladnięcia przez nie. Daniel Wambutda podkreśla, że empiryczne metody badawcze nie mogą ani potwierdzić, ani zaprzeczyć istnieniu demonów z afrykańskich wierzeń ludowych. Wstępem do uzdrowienia tych, którzy wierzą, iż sa opętani przez demony jest uznanie ich istnienia. Przekonywanie chorego o ich nieistnieniu jedynie go zrazi. Poza tym Biblia uznaje istnienie duchowych mocy, ukazując jednocześnie, że Jezus odnosi nad nimi druzgocace zwycięstwo (Kol 2, 15). Wambutda apeluje o zmianę nastawienia Kościoła wobec wierzeń afrykańskich, aby ułatwić Afrykanom odkrycie Chrystusa jako zwycięzcy ${ }^{19}$.

Zajmujący się od wielu lat problematyką zdrowia i uzdrawiania Kongijczyk Jean Masamba ma Mpolo wskazuje na mądrość podejścia rodzimych uzdrowicieli, którzy uznaja „demona” jako reprezentanta zla i nie próbują go utożsamiać z wyraźnie złymi ludźmi, ani nie lekceważą jego działalności jako psychopatologicznych objawów ludzkiego zachowania. Skoro w afrykańskiej duchowości moce sprowadzające chorobę i przynoszące uzdrowienie postrzega się jako zewnętrzne w stosunku do chorego (owładniętego), Kościól powinien dogłębnie przeanalizować miejsce i znaczenie używanych symboli oraz sprawowanych rytuałów. Modlitwy i rytuały trzeba sprawować w taki sposób, by uczestnicy dostrzegali w nich działanie odnawiającego pierwotną harmonię (uzdrawiającego) Boga oraz Jezusa Chrystusa pokonującego moce ciemności i przywracające-

${ }^{17}$ Por. K. A p p i a h-Ku bi: Man Cures, God Heals, dz. cyt. Uzdrowiciele z ludu Sukuma zdecydowanie podzielaja to przekonanie. Uzdrawia Istota Najwyższa, a nie oni. Zob. także - J. H e a l e y, D. S y b e r t z: Towards an African Narrative Theology. Nairobi 1996 s. 301.

${ }^{18}$ U. C. Man us: Miracle Workers/Healers as Divine Men: Their Role in the Nigerian Church and Society. „Asia Journal of Theology”. R. 3: 1989 nr 2 s. 678.

${ }^{19}$ D. N. W a m b ut d a: Bible Studies on Man, Community and Healing. W: Primal WorldViews. Red. J. V. T a y 1 o r. Ibadan 1976 s. 40-41. 
go wszystkich do pełni życia przez chrzest i Eucharystię (Kol 1, 13; 1 Kor 11 , 27-30; Mk 16, 16-17) ${ }^{20}$.

Masamba ma Mpolo podkreśla, że afrykański Kościól powinien dbać o wypełnianie swego powołania do bycia wspólnotą zapobiegawczą i uzdrawiająca. Musi lepiej poznać teologiczne znaczenie afrykańskich rzeczywistości duchowych. Powinno ono prowadzić do rozwijania wlaściwej interpretacji psychologicznej oraz metod terapeutycznych, odnoszących się do takich zjawisk, jak owładnięcie przez demony czy obecność przodków wraz z ich społecznopolitycznymi odniesieniami. Masamba ma Mpolo wskazuje, iż powszechny w Afryce autorytaryzm (w kręgach politycznych, ekonomicznych i religijnych) „zawlaszcza” przodków, by wyzyskiwać ubogich. Dlatego powinno się pomagać ludziom w wypracowywaniu dojrzalej, wyzwalającej duchowości. Przeżywanie tajemnicy Boga w Chrystusie, wyzwolicielu wierzących mogłoby się dokonywać we wzywaniu tradycyjnej opieki przodków i pomocy Ducha Świętego dla wypędzenia wszelkich zlych mocy ${ }^{21}$.

Kościół nie powinien wzbraniać się przed używaniem mocy danej mu przez Jezusa do wypędzania demonów i uzdrawiania. Ta moc została mu dana także do naprawiania systemów i wartości kulturowych, dotąd używanych przez moce zła do wyzyskiwania ubogich. Rodzimy uzdrowiciel uzdrawiał nie tylko jednostki, lecz także całe grupy, włączając w to świat widzialny i niewidzialny. Zatem poważne potraktowanie posługi uzdrawiania przez chrześcijan może pomóc narodom, rządom i Kościołom w podejmowaniu wezwania do nawrócenia, przebaczenia, pojednania i osiągania solidarności ${ }^{22}$.

\section{Rodzimy uzdrowiciel i chrześcijański duchowny}

Wiara w istnienie tajemnej mocy, którą niektórzy ludzie mogą manipulować dla dobra lub na szkodę innych jest w Afryce ciagle silna. Stąd chrześcijanie

${ }^{20} \mathrm{~J}$. M a s a m b a m a M po 10 : Spirituality and Counselling for Healing and Liberation. The Context and Praxis of African Pastoral Activity and Psychoterapy. W: The Church and Healing. Red. E. L a r te y i inni, dz. cyt., s. 28-29.

${ }^{21} \mathrm{~W}$ ramach kościelnych grup ludzie powinni mieć możliwość dzielenia się swoimi proble mami i marzeniami oraz uczyć się je analizować pod kątem biblijnym, politycznym, społecznym i psychologicznym, a także wypracowywać odpowiednie liturgie, oparte na rytuałach i symbolach życia. Kongijczyk wskazał, że w okresie po uzyskaniu politycznej niepodległości niektóre kościoły w państwach Wschodniej Afryki wypracowały wspólnotowe programy opieki w postaci egzorcyzmu, pentakostalnych grup śpiewaczych, modlitwy, nabożeństw pokutnych lub uzdrowieńczych nabożeństw chrzcielnych (tamże, s. 28-30).

${ }^{22}$ Tamże. 
nadal korzystają z pomocy wróżbitów i uzdrowicieli, u nich szukając uzdrowienia i ochrony przed sprowadzająca nieszczęścia zawiścią ludzi. Strach przed staniem się ofiarą czarów jest silniejszy niż np. strach przed popelnieniem grze$\mathrm{chu}^{23}$.

Choć wielu chrześcijańskich duchownych starało się zdyskredytować lokalnych uzdrowicieli, to ich wysilki przyniosły w niektórych wypadkach nieoczekiwany i odwrotny efekt. Uzdrowiciele zaczęli pojawiać się na nowo wzbogaceni o mesjańską interpretację swej posługi. Ugandyjskie medium owładnięte w czasie seansu przez ducha bohatera Kiwanuka wyjaśniło Shorterowi całe zdarzenie, posługując się chrześcijańską symboliką: duch spoczął na medium tak, jak spoczął na Jezusie, przekazując Boże przesłanie dla ludzkości ${ }^{24}$.

Holenderski antropolog i katolicki duchowny Matthew Schoffeleers zauważa, że mimo sprzeciwu ze strony oficjalnych reprezentantów misyjnych Kościolów, wielu rodzimych uzdrowicieli jest praktykującymi chrześcijanami, którzy w swym posługiwaniu sięgaja po chrześcijańską symbolikę. Także uzdrowiciele niechrześcijanie zapożyczają czasami chrześcijańskie idee, symbole i rytuały ${ }^{25}$. Większość tych przemian nie została jednak dostrzeżona przez Kościoły misyjne. Zdaniem Schoffeleersa przemiany te można interpretować jako próbę przyciągnięcia chrześcijan do dawnych praktyk, rzekomo usankcjonowanych użyciem chrześcijańskiej symboliki, jako rywalizację między rodzimymi uzdrowicielami a Kościołami uzdrowicielskimi, albo też jako zwykłą adaptację rodzimych praktyk wróżbiarskich do wymagań stawianych przez władze kolonialne. Warto jednak zwrócić uwagę na fakt, że schrystianizowani uzdrowiciele tworzą specyficzny pomost między rytualnymi uzdrowieniami dokonywanymi w kontekście rodzimym i chrześcijańskim ${ }^{26}$.

${ }^{23}$ J. H e a 1 e y, D. S y b e r t z: Towards an African Narrative Theology, dz. cyt., s. 293.

${ }^{24}$ A. S h o r te r: Jesus and the Witchdoctor. An Approach to Healing and Wholeness. London 1985 s. $9-10$.

${ }^{25} \mathrm{~S}$ c h o f f e l e e r s (Folk Christology, dz. cyt., s. 168) przytacza wyniki badań J. R. C r a w f o r d i A. P. W e n d orf f. Na przełomie lat pięćdziesiątych i sześćdziesiąych XX w. istniała w ówczesnej Rodezji i północno-wschodnim Malawi warstwa wróżbitów, stosujących wróżbiarskie praktyki używane przez proroków kościołów zielonoświątkowych. Wróżbici dystansowali się jednak od tych ostatnich, określając sie jako uzdrowiciele lub pobierając opłaty za swoje usługi. W e n d o r ff wywodzi tę »chrystianizację rytuałów« od ogłoszonego w $1911 \mathrm{r}$. przez brytyjskie władze kolonialne Witchcraft Act, zakazującego wszelkich oskarżeń o czary. Aby nie wejść w konflikt $\mathrm{z}$ prawem, uzdrowiciele starali się upodabniać swoją działalność do rytuałów chrześcijańskich. M. K i rwe n (The Missionary and the Diviner, dz. cyt., s. 83) wspomniał, że wróżbita J o h n nie widział konfliktu w byciu wróżbitą i chrześcijaninem.

${ }^{26}$ M. S c h of f e le e r s: Folk Christology, dz. cyt., s. 168-169. Słynny uzdrowiciel B w a n a l i z Malawi stwierdził w wywiadzie udzielonym w 1974 r., że jego posługa jest doskonalsza od wszystkich dotychczasowych form uzdrawiania. B wanali, zwracając się wylącznie do Boga 
W świadomości wielu afrykańskich chrześcijan rzeczywistości wyrażane przez rodzimego uzdrowiciela i chrześcijańskiego duchownego przenikają się wzajemnie. Chrześcijańscy duszpasterze są często postrzegani jako uzdrowiciele, a w niektórych wypadkach sami zapożyczają elementy działalności rodzimego uzdrowiciela $^{27}$. W Kościołach niezależnych pozycja niektórych proroków uzdrawiających wygląda czasem na uzurpację centralnego miejsca Chrystusa. Wielu misjologów sądzi jednak, iż poprawniejsze jest pojmowanie tej funkcji jako „ikonicznej”. Prorocy odbijajq Chrystusa jak lustro, sq jak okno, przez które wierzqcy widzq Chrystusa ${ }^{28}$. Przy tym trzeba pamiętać, że Chrystusa i chrześcijańskiego duszpasterza postrzega się często w teologii ludowej jako nierozdzielnych.

Kongijczyk Buana R. Kibongi uważa, że autorytet chrześcijańskich duchownych w afrykańskich wspólnotach opiera się w znacznym stopniu na autorytecie wypracowanym przez rodzimego uzdrowiciela. Znajduje to odzwierciedlenie w języku, gdyż duchownego chrześcijańskiego określa się mianem nganga Nzambi (Nzambi - Istota Najwyższa) i uważa się go za duchowo silniejszego i bardziej wplywowego niż nganga mukisi (rodzimy uzdrowiciel). Kirwen pisze, że wróżbita Riana nazywal jego samego (chrześcijańskiego misjonarza) chrześcijańskim wróżbitą i nie był to wyjątek. Badacz sam wskazał zbieżność ról chrześcijańskich duszpasterzy i wróżbitów, gdy przez przepowiadanie, administrowanie, rytuały i poradnictwo oficjalnie interpretują wolę Bożą żyjącym ${ }^{29}$.

Bardzo bliską analogię między wróżbiarstwem i przepowiadaniem dostrzegli także antropolodzy Binsbergen i Schoffeleers stwierdzając, iż w obu wypadkach

przewyższa to, co robił tradycyjny uzdrowiciel. Przewyższa także to, co praktykowane jest w Kościołach, gdyż wierzy w rzeczywistość czarownictwa, podobnie jak jego pacjenci (tamże, s. 176 przyp. 18. M. L. Da n e el (Towards a Theologia Africana?, dz. cyt., s. 85) pisze: $U$ podstaw wszelkich praktyk uzdrowicielskich, bazujacych na wierze (faith-healing) można znaleźć z góry zalożona chrystologie. Faktycznie uzdrawiajacy prorok personifikuje wyzwolicielska i uzdrowicielskq posługe Chrystusa. Przepowiada Chrystusa-uzdrowiciela w czasie nabożeństw poprzedzajacych uzdrowienia. $Z$ jednej strony kontynuuje on zatem tradycje ngangi, ale $z$ drugiej strony radykalnie nadaje jej chrześcijańskq formę. W nakładaniu rak, modlitwach, kropieniu woda święconq $i$ innych symbolach Bożej uzdrowicielskiej mocy oraz $w$ dramatycznym egzorcyzmie zlych duchów Chrystus ukazuje się w świecie afrykańskim jako Ten, który się troszczy, ochrania, odnawia i odpedza strach. Widzimy tu Chrystusa Zwycięzce, który aktualizuje, ponad tradycyjnymi pojeciami, zwycięstwo nad niszczycielskimi mocami.

${ }^{27}$ M. S c h of f e le e r s (Folk Christology, dz. cyt., s. 165) cytuje S u nd k le r a wskazujacego na fakt, że np. zuluskie kościoly syjonistyczne czerpią wzorce posługiwania raczej od rodzimych wróżbitów i łowców czarowników, niż od głównych Kościołów chrześcijańskich.

${ }^{28}$ Tamże, s. 175 przyp. 6 .

${ }^{29}$ R. B u a na Ki b on gi: La prêtrise. W: Pour une théologie africaine. Red. K. D i ck son, P. Ellingworth. Yaoundé 1969 s. 77-78; M. Kirwen: The Missionary and the Diviner, dz. cyt., s. 91. 
kreowane jest znaczenie wlaściwe dla aktualnej sytuacji (tak jak postrzegaja ja pacjenci czy liturgiczne zgromadzenie ${ }^{30}$. Natomiast Shorter, ukazując zbieżność wróżbiarstwa praktykowanego przez Afrykanów z formami proroctwa, dostrzega w nich powód konfliktów, jakie zaistniały między pierwszymi misjonarzami a wróżbitami $^{31}$. Ghańczyk Abraham Berinyuu stwierdza, iż nazywanie duchownych chrześcijańskich wróżbitami w Afryce jest uprawnione, skoro akańskie słowo osofo, którym określają ich ludzie, zawiera odniesienie do wróżbiarstwa ${ }^{32}$.

Według Berinyuu ludzie, zwracając się ze swoimi problemami do duchownych, chcą zrozumieć tajemnice życia, a choroba jest jedną z nich. Muszą zatem istnieć „chrześcijańscy wróżbici”, którzy - podobnie jak ich rodzimi odpowiednicy - wejdą ze swoim pacjentem w relację. Międzyosobowa relacja jest w pojęciu afrykańskim częścia procesu leczenia, który nie ogranicza się jedynie (wzorem europejskim) do zebrania informacji w celu postawienia diagnozy i wyboru wlaściwej terapii. Chrześcijański wróżbita powinien być „słuchaczem opowieści”, a jego zadaniem jest pomóc choremu właściwie zinterpretować dane doświadczenie w relacji do Chrystusa ${ }^{33}$. Chrześcijański wróżbita ma także interpretować i integrować chrześcijańską teologię oraz kulturę afrykańską. Jak Jezus swoją uzdrowicielską posługą inaugurowal królestwo Boże, tak ma je inaugurować chrześcijański wróżbita, z szacunkiem traktując funkcje sprawowane przez rodzimego uzdrowiciela ${ }^{34}$.

Rytuały uzdrowienia, przebaczenia i pojednania stanowią trwały element afrykańskiej codzienności, dlatego nie należy ich lekceważyć. Berinyuu stwierdza, że działając we wspólnocie, której członkami są nie tylko chrześcijanie,

${ }^{30}$ W. van Bins berge n, M. S ch of feleers (eds.): Theoretical Explorations in African Religion. London 1985 s. 8.

31 [...] misja niosła ze sobq konkurencyjnq forme uzdrawiania i objawiania (A. S h o r t e r: Jesus and the Witchdoctor, dz. cyt., s. 9).

${ }^{32}$ A. A. B e r i n y u u: Pastoral Care for the Sick in Africa. An Approach to Transcultural Pastoral Theology. Frankfurt a. Main 1988 s. 93.

${ }^{33}$ Zaskakująco B e r i n y u u wskazuje także na paralelę z H e r m e s e m. Od niego też ludzie oczekiwali pomocy w zrozumieniu tajemnic życia. Chrześcijański wróżbita, podobnie jak He r $\mathrm{mes}$, jest zwiastunem dobrej nowiny (tamże, s. 93-96). Chrześcijański wróżbita w aktywnym sluchaniu musi poszukiwać sposobu nadania sensu i znaczenia chorobie teologicznie (tamże, s. 98). K. A p p i a h - K u b i (The Church's Healing Ministry, dz. cyt., s. 238) sugeruje, że kościelne szpitale mogłyby zatrudnić rodzimych ekspertôw medycznych, którzy jeździliby na wezwania do chorego i w procesie wróżbiarskim wspólnie z nim odkrywali przyczynę jego choroby, mając możliwość organizowania nabożeństw paraliturgicznych. Jednak K. A p p iah-Kubi (Traditional African Healing System Versus Western Medicine in Southern Ghana: an Encounter. W: J. O 1 u p o n a, S. N y a n g [eds.]: Religious Plurality in Africa. Berlin 1993 s. 106) preferuje komplementarność, a nie integrację obu systemów. W tym ujęciu oba systemy - europejski i afrykański rozwijają się we własnych ramach i dzielą się osiągnięciami.

${ }^{34}$ Por. A. A. B e r in y u u: Pastoral Care for the Sick, dz. cyt., s. 98. 
chrześcijański wróżbita powinien wykorzystać swą posługę do mądrego dawania świadectwa. Dla chrześcijan z lokalnej wspólnoty, każdy element jego posługi musi być wyraźnym uobecnianiem dziel Chrystusa, pierwszego przodka. Skoro Chrystus jest Panem wszystkiego, to zadaniem chrześcijańskich wróżbitów jest używanie wszystkich znaków i symboli, wyrażających wiarę, uczucia i doświadczenie afrykańskich chrześcijan ${ }^{35}$.

Chrześcijański wróżbita musi w swej posłudze uwzględnić tak nieodłącznie (w ujęciu afrykańskim) związane $\mathrm{z}$ chorobą zagadnienia, jak czarownictwo, związek grzechu i choroby oraz znaczenie rytuałów ofiarniczych. Mocno wpisany w światopogląd Afrykanów fenomen czarownictwa powinien być objęty duszpasterską troską o chorych, a nie traktowany jako zabobon, gdyż często sygnalizuje on nierozwiązane osobiste lub wspólnotowe konflikty, trapiące ludzi i objawiające się także na płaszczyźnie zdrowia fizycznego. Afrykańskie społeczności znają sposoby rozwiązywania tych konfliktów i wróżbita chrześcijański może ich użyć, pomagając cierpiącym wyrazić problem, uznać winę, prosić o przebaczenie lub go udzielać, wreszcie dokonywać pojednania. $W$ zmaganiach $z$ powodującym chorobę czarownictwem chrześcijański wróżbita powinien szukać odpowiedzi na chrystologiczne pytanie: dlaczego wszechmocny i kochający Bóg nie uwalnia ludzi z mocy sprowadzających zło czarowników i nie uzdrawia ich? Zdaniem Berinyuu kontekst choroby najwyraźniej ukazuje, w jaki sposób chrześcijanie przeżywają swoją relację z Bogiem i jak adekwatne są tytuly, którymi zwykle Go określają. Kontekst ten skłania chrześcijan do tworzenia bardziej inkarnacyjnej chrystologii wyrażanej w rodzimych sformułowaniach ${ }^{36}$.

Spogląając na sytuację w ogólno-afrykańskiej perspektywie Kolié uważa, że współcześni terapeuci w Afryce działają w trzech nurtach. W ramach pierwszego mieszczą się ci, którzy w sytuacji rozpadu rodzimego porządku społecznego starają się odnowić osobowość Afrykanów i pomóc im odrodzić się do stawienia czoła wymaganiom nowego świata (np. działalność proroka Atcho z Wybrzeża Kości Słoniowej). W ramach drugiego nurtu Kolié umieszcza chrześcijan, którzy przechodząc inicjację rodzimego uzdrowiciela ukazują, w jaki sposób rodzimi terapeuci trzymaja pod kontrola problemy związane z czarownictwem i ukrytą przemocą w afrykańskich społecznościach (np. Eric de Rosny SJ). Trzeci nurt reprezentują uzdrowiciele charyzmatyczni (np. Meinrad Hebga SJ) ${ }^{37}$.

\footnotetext{
${ }^{35}$ Tamże, s. 100 i 104.

${ }^{36}$ Tamże, s. 99-101.

${ }^{37}$ C. K o 1 i é: Jésus guérisseur?, dz. cyt., s. 179.
} 


\section{Przykład nieobojętny - Emmanuel Milingo}

Chociaż Emmanuel Milingo należy do tej części chrześcijańskich duchownych, którzy odrzucaja postrzeganie ich jako rodzimych uzdrowicieli, to zdaniem Schoffeleersa, nie oznacza to, iż odrzucaja oni zupełnie sam model rodzimego uzdrowiciela. Milingo w zasadzie potwierdza, że wzoruje się na nim. Według Holendra trzeba na to zagadnienie spojrzeć w kategoriach pozytywnej i negatywnej identyfikacji, gdyż oba przeciwstawne podejścia są wywoływane i ksztaltowane przez ten sam podstawowy obraz. Schoffeleers twierdzi, że prowadzona przez Kościoły chrześcijańskie posługa uzdrawiania jest w istocie przemianą roli rodzimego uzdrowiciela. To, co robią chrześcijanie w zakresie uzdrawiania odnosi się do tych samych ludzkich problemów, którymi zajmuje się uzdrowiciel, chociaż widza je w zupełnie innej perspektywie teologicznej i stosują odmienne techniki rytualne ${ }^{38}$.

W pojęciu wyznawców religii rodzimych i wielu afrykańskich chrześcijan rodzimy uzdrowiciel spełnia niezwykle istotną rolę dzięki fenomenowi owładnięcia przez duchy, co daje mu dostęp do nadnaturalnych mocy. Tego fenomenu nie można zignorować, rozpatrując chrześcijańską posługę uzdrawiania. Chociaż uczeni próbowali wytłumaczyć duchy jako prymitywną interpretację sił społecznych, psychologicznych i fizjologicznych, to Appiah-Kubi zapytuje, w jaki sposób współcześni wierzacy mają wytłumaczyć sobie wypadki owładnięcia przez duchy opisane w Biblii? Misyjne Kościoły nadal wykazują tendencję do potępiania rodzimych praktyk religijno-medycznych jako służących złu, a owładnięcie przez duchy w kategoriach zaburzeń psychicznych. Appiah-Kubi ukazuje jednak, że sytuacja jest bardziej złożona niż wielu przedstawicieli Kościołów misyjnych jest skłonnych przyznać ${ }^{39}$.

Chrześcijańska posługa uzdrawiania nie może ignorować faktu, że wielu Afrykanów wierzy, iż obecne w świecie nadnaturalne moce moga ujawnić się w formie duchów przejmujących kontrolę nad ciałem i umysłem czlowieka.

\footnotetext{
${ }^{38}$ Pozytywna identyfikacja pojawia się, gdy akceptuje się pewien model, a szczególnie, gdy się z nim współzawodniczy. Identyfikacja negatywna jest dezaprobatą jakiegoś modelu, szczególnie gdy chce się od niego zdystansować. M. S c h of f e l e e r s (Folk Christology, dz. cyt., s. 166-167) sądzi, że nie ma powodu uważać, by pozytywna identyfikacja była silniejsza w kształtowaniu ludzkiego zachowania niż identyfikacja negatywna.

${ }^{39}$ Por. K. A p p i a h - K u b i: The Church's Healing Ministry, dz. cyt., s. 232-235. We wstepie do swojej książki Ki r w e n (The Missionary and the Diviner, dz. cyt., s. XV) opisal zdarzenie, $\mathrm{w}$ którym zaproszony na spotkanie $\mathrm{z}$ chrześcijanami wróżbita zapowiedział niebezpieczeństwa $\mathrm{w}$ drodze do domu. Nastapiło poruszenie, ale: nikt nie watpil $w$ moc wróżbity ani $W$ wizję świata, która istnienie tej mocy zakładala. To, co robil i mówił było natychmiast rozumiane $i$ uznawane przez wszystkich. W tłumie bylo niewielu takich, którzy nie korzystali z posługi wróżbitów, nawet po tym, jak zostali ochrzczeni.
} 
Owładnięcie przez duchy jest zjawiskiem znanym większości współczesnych społeczeństw i w naukowej literaturze określa się je terminem „zmienione stany świadomości". Antropologiczne badania wskazuja, że zdecydowanie negatywne podejście do tego zjawiska prezentowane $w$ ramach kultury zachodniej, w tym zachodniego chrześcijaństwa, jest nietypowe. Holenderska antropolog Gerrie ter Haar stwierdza zatem, że »owładnięcie« jest religıjnym określeniem wyrażajqcym wiarę, iż $w$ danq osobę, okazujqcq określone objawy, wszedl niewidzialny byt, $w$ istnienie i moc którego ludzie wierzq. Społeczeństwa, uznające zjawisko owładnięcia przez duchy, poddają je rytualnej kontroli. Chociaż zdarzają się wypadki opętania, czyli owładnięcia człowieka przez demona, to zasadniczo owładnięcie jest zachowaniem, które można nauczyć się kontrolować ${ }^{40}$.

Tymczasem wielu chrześcijańskich duchownych w Afryce jest przekonanych, że wraz z rozwojem szkolnictwa i służby zdrowia fenomen owładnięcia przez duchy zaniknie. Usilne podtrzymywanie tego przekonania doprowadziło spoleczeństwa Zachodu do utraty rytualnej kontroli nad fenomenem owladnięcia. Przeniesienie go na grunt afrykański spowodowało zmianę nastawienia do zjawiska owładnięcia, przynosząc nieoczekiwane skutki negatywne ${ }^{41}$.

Owladnięcie jest środkiem komunikacji między światem widzialnym i niewidzialnym, dlatego rozwijające się negatywne postrzeganie owładnięcia przez duchy i nowe określanie całej grupy duchów, dotąd uważanych za neutralne, mianem „złe duchy” spowodowało zachwianie równowagi między tymi światami. Ter Haar podaje, że dla wielu Zambijczyków owładnięcie utraciło swoja wcześniejszą rolę komunikacyjną. Jednak ludzie nie przestali postrzegać swoich dolegliwości jako skutków działalności duchów. Ponieważ uzdrowienia dokonywały się bardzo często w kontekście owładnięcia przez duchy, znalezienie uzdrowienia w nowo zaistniałej sytuacji zostało mocno utrudnione. Kościoły misyjne lekceważyły problem, narzucając jednocześnie interpretację duchów i owładnięcia przez nie w kategoriach zła ${ }^{42}$.

Analizując problem Ter Haar stwierdziła, że Milingo nie tylko dostrzegł powstałe zamieszanie i zagubienie wielu Afrykanów w zaistniałej sytuacji, ale podją kroki mające na celu przywrócenie ładu. Lękowi wywoływanemu przez złe duchy Milingo przeciwstawił moc płynąca od najpotężniejszego ducha dobra - Ducha Świętego. W zamyśle Milingo Duch Święty miał napełniać cierpiących, wypierając złe duchy wraz ze wszystkim, co one powodowały. W ten sposób cierpiący stawali się „mediami” Ducha Świętego. Takie podejście nadawało

${ }^{40}$ G. Te r H a a r: Spirit of Africa. The Healing Ministry of Archbishop Milingo of Zambia. London 1992 s. 117-119, 121.

${ }^{41}$ Tamże, s. 120-121.

${ }^{42}$ Tamże, s. 123-125. 
zupełnie nową, chrześcijańską interpretację rodzimym wierzeniom związanym z owładnięciem, a Milingo uzasadniał je sięgając do orzeczeń Soboru Watykańskiego II, przyznających prawo wszystkim ludom do wyrażania doświadczenia Boga we wlasny sposób. Ter Haar ubolewa, że zastosowane przez Milingo rozwiązanie zostało odebrane przez najwyższe kościelne władze jako podważające ich autorytet ${ }^{43}$.

Kierowane przeciw Milingo zarzuty o praktyczne umacnianie przeświadczenia, iż to zle duchy są sprawcami cierpienia tracą swoją moc, gdy uwzględni się caly proces rozwoju chrześcijaństwa w Afryce. Do umacniania tego przeświadczenia przyczynila się głównie praktyka demonizowania rodzimego świata duchów rozpoczęta przez pierwszych misjonarzy. Ter Haar uważa, że Milingo poważnie wsłuchał się w obawy i problemy trapiące ludzi, a także podjął działania mające na celu uporządkowanie powstałego zamieszania. Uzdrowicielska działalność Milingo nie tylko przynosiła ludziom uwolnienie od cierpień, ale dawała jednocześnie przekonanie o umocnieniu Duchem Świętym, dzięki któremu ludzie odzyskiwali utraconą wiarę w siebie (w podobny sposób funkcjonują rytuały religii rodzimych). Nabierającą $w$ ten sposób odniesienia społecznego działalność Milingo zambijskie elity polityczne i kościelne odczytały jako zagrożenie dla status quo ${ }^{44}$.

Ter Haar i Adrian Hastings podkreślaja, że wiara w Chrystusa i mocne poczucie afrykańskiej godności były dwoma źródłami inspiracji dla Milingo ${ }^{45}$. Tro-

\footnotetext{
${ }^{43}$ Zdaniem T e r H a a r sprawa M i 1 i n g o ukazuje, że spora część hierarchii Kościoła katolickiego uznaje, iż Duch Święty może przemawiać tylko przez centrum, czyli watykańską elitę i jedynie w jej języku oraz za pośrednictwem jej środków wyrazu, a nie w języku używanym w Afryce (tamże, s. 127-130). Także A. H a s t ing s (African Catholicism: Essays in Discovery. London 1989 s. 155) ubolewa, iż skuteczność zaangażowania M i 1 i n g o w posługę uzdrawiania w jego afrykańskim rozumieniu została zneutralizowana przez przeniesienie arcybiskupa do Europy.

${ }^{44}$ Wiele ludów żyjących na terenach dzisiejszej Zambii oczekiwało nadejścia L u c e le N g a n g a - „Jutrzenkowego Uzdrowiciela”, „Posłańca Światła”. Niektórzy dopatrywali się realizacji tego oczekiwania w osobie Milingo. Lumpa Church, Kościół założony przez Alice Le n s h i na, uznawał Jezusa za ucieleśnienie Posłańca Światła (por. G. Te r Ha ar: Spirit of Africa, dz. cyt., s. 126-128). Chociaż A. Ha s t in g s (African Catholicism, dz. cyt., s. 154) dystansuje się od niektórych poglądów Miling o i stwierdza, że oficjalne wystapienia przeciw zjawiskom owładnięcia przez duchy i czarownictwu mogą wywołać niezdrową reakcję inicjującą te zjawiska, to trzeba uznać skuteczność działań Mi 1 i n g o. Ludzie niepodzielający jego przekonań powinni być ostrożni z pogardliwym odrzucaniem jego działalności, gdyż nie mają nic do zaoferowania w zamian.

${ }^{45}$ Por. G. Te r H a a r: Spirit of Africa, dz. cyt., s. 135; A. Has ting s: African Catholicism, dz. cyt., s. 154. Ha st ing s (s. 139) stwierdza, że arcybiskupa krytykowano głównie za mieszanie afrykańskiej tradycji z chrześcijaństwem i zaniedbywanie swoich podstawowych obowiązków. Choć ataki na niego były częściowo oparte na niedoinformowaniu i nie zawsze na czystych motywach, to sam Miling o także nieroztropnie atakował ludzi o nastawieniu bardziej intelektualistycznym.
} 
ska o to, by także inni docenili to drugie źródło spowodowała postrzeganie Milingo jako zajmującego się reaktywowaniem przeszlości. Shorter dopatrywał się w poglądach Milingo zbieżności z europejską, piętnastowieczną demonofobią $\mathbf{i}$ ostrzegal przed jej skutkami. Tymczasem Schoffeleers wskazywal, iż działalność Milingo jest pomostem wiodącym w nowe ${ }^{46}$.

Shorter, widząc trudności doktrynalne płynące $\mathrm{z}$ odmiennych podejść pastoralnych, zastanawial się czy chrześcijański egzorcysta swoim działaniem narzuca afrykańskim chrześcijanom swoją własną koncepcję demonicznego opętania, czy też jest odbierany przez nich bardziej jako ktoś, niosący im potrzebną pomoc $\mathrm{w}$ sytuacji kryzysowej na wzór medium ze wspólnoty strapienia? Przed pierwsza ewentualnością Shorter ostrzegał, natomiast druga wymagalaby jasnego uznania istnienia szkodzących duchów i wypracowania rytualnych środków radzenia sobie z ich działalnością ${ }^{47}$. Shorter nie wydaje się być skłonnym do jej przyjęcia $^{48}$. Hastings twierdzi, że krytyka Shortera jest nieco chybiona, bo Milingo nie narzucał swojej teorii demonologii na całość afrykańskich zjawisk mediumicznych. Jeśli przekonania Milingo wydają się być bliskie piętnastowiecznym czarowniczym fobiom, to są one równie bliskie lokalnym formom afrykańskich tradycyjnych wierzeń dotyczących czarowników i znajdowały się raczej na obrzeżach calości działań podejmowanych przez arcybiskupa ${ }^{49}$.

Poruszona w tym artykule problematyka dotyczy samego wzorca sprawowania chrześcijańskiej posługi uzdrawiania, jak i jego praktycznych aplikacji. Obie sprawy wywołują sporo emocji i prowokują krytykę. Jednym z istotniejszych problemów wydaje się być niekompatybilność sposobów postrzegania świata przez chrześcijan ukształtowanych w pooświeceniowej kulturze Zachodu i rodzimych kulturach Afryki. Dla zdecydowanej większości afrykańskich chrześcijan niewidzialny świat duchowy stanowi integralną część świata, w którym żyje

${ }^{46}$ Por. G. Te r H a a r: Spirit of Africa, dz. cyt., s. 137.

${ }^{47}$ Pisano wcześniej o wypadku wprowadzenia rytuału egzorcyzmującego duchy, który został skrytykowany przez większość duchownych, a zyskał wielkie poparcie wśród wiernych (A. S h o r te r: Mediumship, Exorcism and Christian Healing, dz. cyt., s. 31-32. W kontekście przenoszenia własnego rozumienia zjawisk na nowy kontekst $\mathrm{Cla}$ la de Rivière (Socioanthropologie des religions. Paris 1997 s. 128) pyta: Czy to nie chrześcijańska teologia inkwizytorów zdemonizowala magie i czarownictwo między $X V$ a XVII wiekiem?.

${ }^{48}$ Ilustracja byłoby wydarzenie opisane przez Michaela S in gle t on a, które S h orter najpierw przytoczył jako pozytywny przykład, a kilka lat później skrytykował w swojej książce (M. S ing le to n: Spirits and Spiritual Direction. W: Christianity in Independent Africa. Red. E. F a s h o lé - L u k e i inni. London 1978 s. 471-478); zob. także - A. S h o r te r: Jesus and the Witchdoctor, dz. cyt., s. 184.

${ }^{49}$ Por. A. H a s ting s: African Catholicism, dz. cyt., s. 150. 
się na co dzień. Duchowe byty nie tylko sa uznawane za realnie istniejące, ale wierzy się w ich faktyczne oddziaływanie na zamieszkujących świat widzialny. Tymczasem dla chrześcijan w Europie świat niewidzialny jest pozostaje nie tylko czymś zupełnie odrębnym, ale i odleglym, a nawet nierzeczywistym, nie mówiąc już o wierze w zamieszkujące go byty duchowe. Ta odmienność światopoglądów wiąże się z koniecznością rozwijania odmiennej teologii i wypracowywania zupełnie innej niż w Europie praktyki pastoralnej. Na obecnym etapie wielu chrześcijanom taka sytuacja wydaje się sprzeczna z zachowywaniem jedności Kościoła. Niemniej jednak afrykańskie rozumienie zdrowia i choroby, a także podkreślanie roli posługi uzdrawiania przynosi chrześcijanom o pooświeceniowej mentalności nowe spojrzenie na te zagadnienia i stawia przed wyzwaniami, które wydawały się już zupełnie przebrzmiałe. Zatem konieczne jest dalsze poglębianie rozumienia zagadnień chrześcijańskiej posługi uzdrawiania w Afryce i poszukiwanie sposobów powiązania ze sobą odmiennych wizji świata we wspólnym zwracaniu się ku zbawczemu wydarzeniu Jezusa Chrystusa. 
